\title{
REVIEW
}

\section{Nuclear Receptor Mediated Gene Regulation through Chromatin Remodeling and Histone Modifications}

\author{
MASAHIKO KISHIMOTO*, RYOJI FUJIKI*, SHINICHIRO TAKEZAWA*, YASUMASA SASAKI*, \\ TAKASHI NAKAMURA*,**, KAZUYOSHI YAMAOKA*,**, HIROCHIKA KITAGAWA* \\ AND SHIGEAKI KATO*,** \\ *Institute of Molecular and Cellular Biosciences, University of Tokyo, 1-1-1 Yayoi, Bunkyo-ku, Tokyo 113-0032, Japan \\ **ERATO, Japan Science and Technology Agency, Kawaguchi, Saitama 332-0012, Japan
}

\begin{abstract}
Nuclear steroid/thyroid vitamin A/D receptor genes form a gene superfamily and encode DNA-binding transcription factors that control the transcription of target genes in a ligand-dependent manner. It has become clear that chromatin remodeling and the modification of histones, the main components of chromatin, play crucial roles in gene transcription, and many distinct classes of NR-interacting co-regulators have been identified that perform significant roles in gene transcription. Since NR dysfunction can lead to the onset or progression of endocrine disease, elucidation of the mechanisms of gene regulation mediated by NRs, as well as the identification and characterization of co-regulator complexes (especially chromatin remodeling and histone-modifying complexes), is essential not only for better understanding of NR ligand function, but also for pathophysiological studies and the development of therapeutic interventions in humans.
\end{abstract}

(Endocrine Journal 53: 157-172, 2006)

\section{The Nuclear Receptor Gene Superfamily \\ A. Biological functions of nuclear receptors (NRs) \\ B. NR structure}

II. Decoding of Histone Signals and Regulation of Gene Expression

A. Chromatin structure and histone modifications

B. Chromatin remodeling

III. Chromatin Regulation by NRs

A. Ligand-induced co-regulator switching by NRs

B. Chromatin modifications by NRs

C. Chromatin remodeling by ATP-dependent chromatin remodeling complexes and NRS

IV. NR Co-regulators and Co-regulator Complexes

A. NR AF-2 co-activators

B. AF-1 co-activators of NRs

C. Co-repressors of NRs

V. Perspectives

Correspondence to: Dr. Shigeaki KATO, Institute of Molecular and Cellular Biosciences, University of Tokyo, Yayoi, Bunkyo-ku, Tokyo 113-0032, Japan

\section{The Nuclear Receptor Gene Superfamily}

\section{A. Biological functions of nuclear receptors (NRs)}

Fat-soluble ligands, such as steroid/thyroid and vitamin $\mathrm{A} / \mathrm{D}$, exert a wide variety of biological effects through the transcriptional regulation of target genes via cognate NRs that exhibit specific ligand binding (see Fig. 1). Therefore, NRs are associated with cellular proliferation/differentiation events and are involved in a variety of functions in different cell types. Indeed, NRs are thought to be central to homeostasis as well as the development of clinical pathology in human beings. The physiological importance of the $48 \mathrm{NR}$ family members currently recognized in human beings has been verified in mouse genetic models (Table 1) [1-37]. For instance, peroxisome proliferator-activated receptor (PPAR $\gamma)$, a principal factor in the regulation of adipocyte differentiation and fat storage, has been shown to control glucose tolerance via the general regulation of insulin sensitivity $[38,39]$. Indeed, the PPAR $\gamma$ agonist thiazolidinedione has been used successfully in the clinical treatment of Type II diabetes mellitus. Likewise, fibrate, an agonist of the PPAR $\gamma$ - 


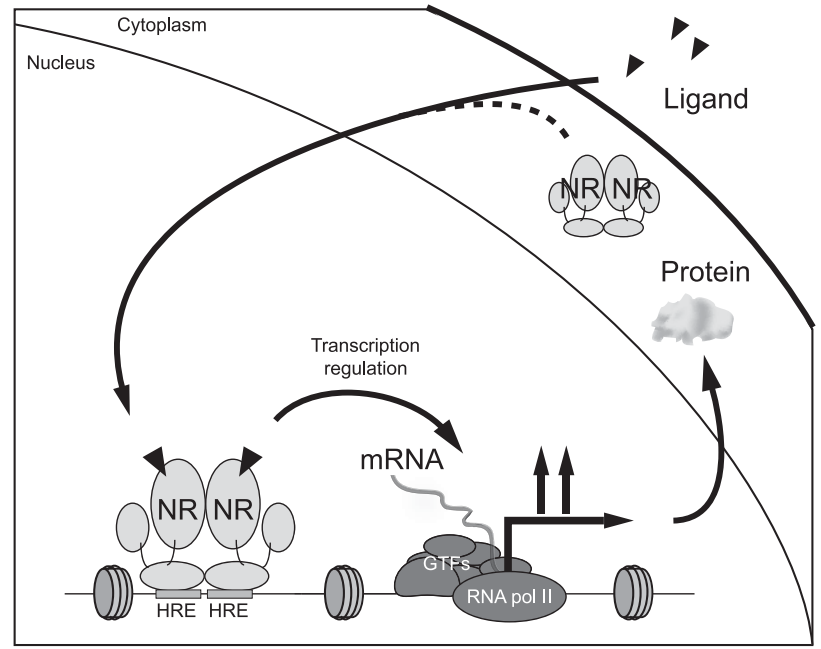

Fig. 1. Nuclear receptor controls expression of target genes in a ligand-dependent manner.

Lipophilic ligands, such as fat-soluble vitamins A and D, as well as thyroid/steroid hormones, are thought to exert their physiological effects through transcriptional control by the cognate nuclear receptors (NRs). NRs recognize and bind with the specific recognition sites, termed hormone responsive elements (HREs). Ligand binding to NRs induces association with general transcription factors (GTFs) and the target genes are transcribed by RNA polymerase II (RNApol II).

related protein PPAR $\alpha$, has been used to treat hyperlipidemia, as PPAR $\alpha$ regulates the expression of genes associated with lipid metabolism, including the lipoprotein lipase (LPL) gene that promotes the catabolism of chylomicron, very low density lipoprotein (VLDL), and intermediate density lipoprotein (IDL), with suppression of fatty acid synthesis in the liver and suppression of triglyceride (TG) production [40-42]. Sex hormone antagonists are also effective against sex hormone-dependent tumors of reproductive organs, breast, and prostate [43-45].

Reflecting the significance of NR functions in the biological effects of NR ligands, NR gene mutations underlie a range of genetic diseases. For example, mutations in coding regions of the androgen receptor (AR) can lead to complete loss of the androgen response, resulting in testicular feminization (Tfm) [46], and unusually expanded polyglutamine repeats within the AR A/B domain lead to spinal and bulbar muscular atrophy (SBMA) [47]. Genetic mutations in the vitamin D receptor (VDR) that result in the loss of vitamin $\mathrm{D}$ responsiveness cause hereditary vitamin D-resistant rickets type II (HVDRR) [48], while thyroid hormone resistance syndrome (RTH) is due to mutation of the thyroid hormone receptor (TR)- $\beta$ gene [49]. Genetic disease also results from the malfunction of nuclear orphan receptors (i.e. those with unknown ligands). For example, several hepatocyte nuclear factor (HNF)$4 \alpha$ gene mutations are known to cause maturity onset diabetes mellitus of the young (MODY)-1 [50], while photoreceptor-cell specific NR (PNR) mutations lead to enhanced S-cone syndrome [51].

\section{B. NR structure}

All NR genes are thought to have evolutionarily developed from a single ancestor gene, such that in metazoans, the NR gene superfamily is found in all genomes from $C$. elegans to human. As all NR superfamily members share structural and functional characteristics that reflect this evolutionary relationship, NR proteins contain five functional domains designated A to $\mathrm{E}[52,53]$ (Fig. 2). The A/B domain contains the activation function (AF)-1 region that is constitutively active even without ligand binding. The highlyconserved DNA binding domain (DBD) is located within the $\mathrm{C}$ domain, while the $\mathrm{D}$ domain contains the nuclear localization signal (NLS) [54]. The moderatelyconserved ligand binding domain (LBD) is mapped to the $\mathrm{E}$ domain, and consists of approximately 250 mostly hydrophobic amino acids that form a ligand-binding pocket made up of $12 \alpha$-helixes present in most of NRs. This domain plays a critical role in activation function (AF)-2 activity, which is induced by ligand binding, and results in clear shifting of the $\mathrm{C}$ terminalmost $\alpha$-helix 12 [55]. As the ratio between AF-1 and AF-2 is dependent on the tissue and cell type, AF-1 and AF-2 activities are probably controlled through a diverse range of molecular mechanisms. Of the $12 \alpha-$ helixes encoded by the LBD E domain, specific ligands bind to a hydrophobic cave formed by $\alpha$-helices 3,4 and 5. Ligand binding induces a structural alteration in the E domain, mainly in terms of movement of the $\alpha$ helix 12. For ER $\alpha$ the angle of this $\alpha$-helix 12 shift has been reported to vary according to ligand type [56, 57], and appears to define the transactivation function. In contrast, NR AF-1 domains appear to mediate specific intracellular functions as the conservation of $\mathrm{A} / \mathrm{B}$ domain amino acid sequences between NRs is low. While intramolecular interaction between AF-1 and AF-2 functions in gene regulation has been well described $[58,59]$, its molecular basis with respect to 
Table 1.

glucocorticoid receptor (GR)

impaired lung development (most of the mutant mice died during the perinatal period), [increase of corticosterone and ACTH in heterozygous mice] (33)

mineralocorticoid receptor (MR)

hyperkalemia, hyponatremia (pseudohypoaldosteronism) (4)

androgen receptor (AR)

testicular feminization ( $\mathrm{Tfm}$ ) and osteopenia in the male mutant mice, abnormal brain masculinization $(16,32)$

progesterone receptor (PR)

pleiotropic reproductive abnormalities (25)

estrogen receptor (ER) $\alpha$

infertility (22)

ER $\beta$

reduction in fertility $(12,19)$

retinoic acid receptor (RAR) $\alpha$

high postnatal lethality, testis degeneration (23)

retinoic acid receptor (RAR) $\beta$

no abnormality (14)

retinoic acid receptor (RAR) $\gamma$

growth deficiency, early lethality, male infertility (21)

thyroid hormone receptor (TR) $\alpha$

reduced linear growth, bone maturation delay, moderate hypothermia, reduced thickness of the intestinal mucosa (9)

thyroid hormone receptor (TR) $\beta$

resistance to thyroid hormone (8), deficit in auditory function (7)

Vitamin D receptor (VDR)

growth retardation, alopoecia, hypocalcemia, impaired bone formation (36)

peroxisome proliferator-activated receptor (PPAR) $\alpha$

lipid accumulation in the livers of fasted or high fat diet mutant mice $(17,20)$

peroxisome proliferator-activated receptor (PPAR) $\beta / \delta$

embryonic lethal, growth retardation in surviving mice (30)

peroxisome proliferator-activated receptor (PPAR) $\gamma$

embryonic lethal, [protection from high fat diet induced adipocyte hypertrophy and insulin resistance in heterozygous mice] (38, 39)

liver $\mathrm{X}$ receptor $(\mathrm{LXR}) \alpha$

loss of normal response to dietary cholesterol (28)

liver $\mathrm{X}$ receptor (LXR) $\beta$

no apparent abnormal phenotype (2)

farnesoid $X$ receptor (FXR)

elevation of serum bile acid, cholesterol, and triglycerides levels (34)

pregnenolone $\mathrm{X}$ receptor $(\mathrm{PXR}) /$ steroid and xenobiotic receptor (SXR)

loss of normal response to xenobiotic treatment (18)

retinoid $\mathrm{X}$ receptor $(\mathrm{RXR}) \alpha$

embryonic lethal, [growth deficiency in heterozygous mice] (13)

retinoid $X$ receptor $(\mathrm{RXR}) \beta$

embryonic lethal, male infertility in surviving mice (15)

retinoid $\mathrm{X}$ receptor $(\mathrm{RXR}) \gamma$

central resistance to thyroid hormone (5), less weight gain when fed a high fat diet (11)

photoreceptor-specific nuclear receptor (PNR)

retinal degeneration (1)

TLX

reduction in the size of rhinencephalic and limbic structures, including the olfactory, infrarhinal and entorhinal cortex (26, 37)

hepatocyte nuclear factor (HNF) $4 \alpha$

embryonic lethal (6)

retinoid-related orphan receptor (ROR) $\alpha$

cerebellar defects (10)

retinoid-related orphan receptor (ROR) $\beta$

retinal degeneration (3)

retinoid-related orphan receptor (ROR) $\gamma$

absence of lymph node (35)

adrenal-4 binding protein (Ad4BP)/steroidogenic factor (SF)-1

lack of adrenal glands and gonads, structural and functional abnormalities in spleen $(24,27)$

chicken ovalbumin upstream promoter-transcription factor (COUP-TF) I

defects in morphogenesis of the glossopharyngeal ganglion, axonal projection, and arborization (31)

COUP-TF II

embryonic lethal (29) 
A

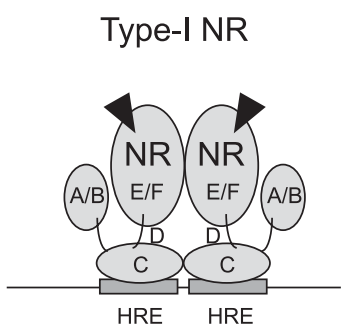

Type-II NR

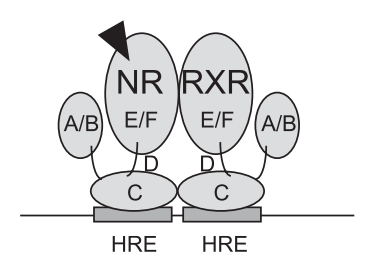

B

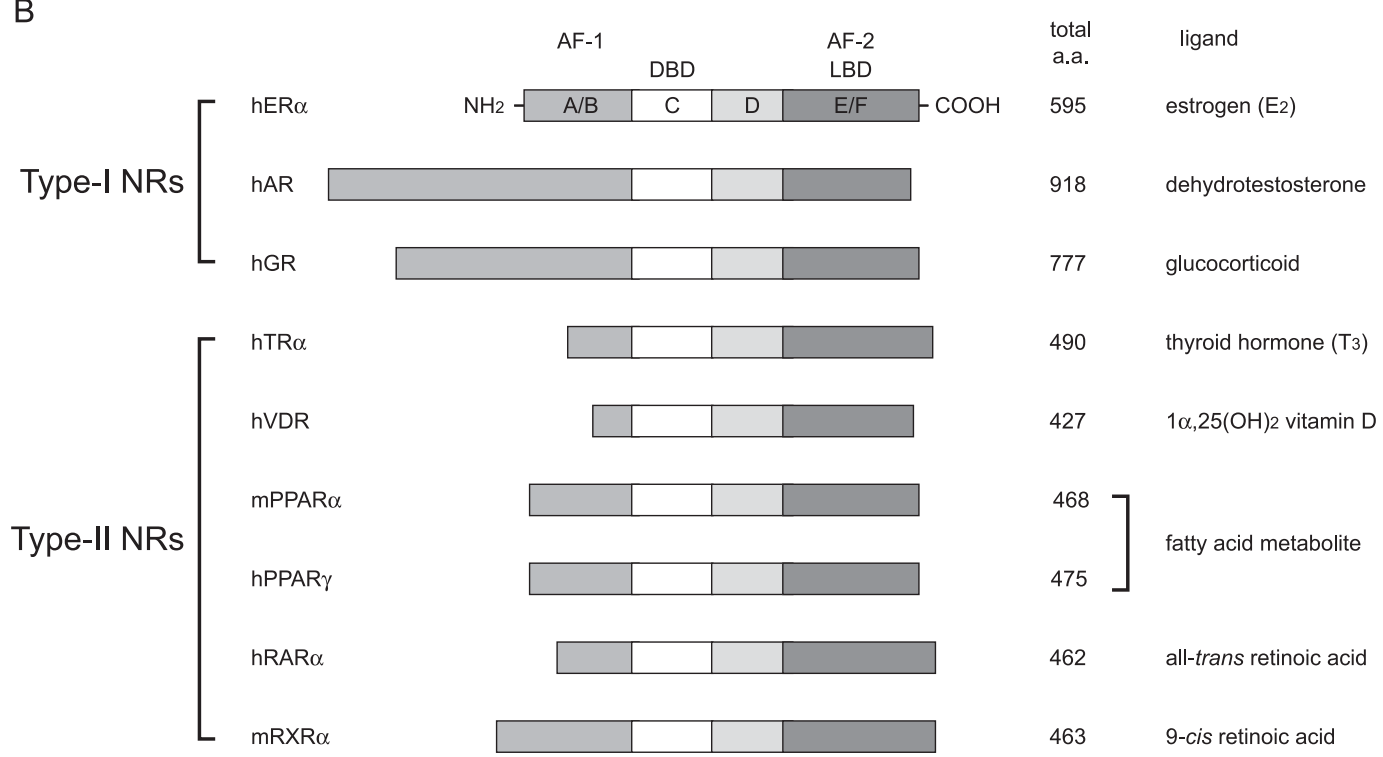

Fig. 2. Structure and function of nuclear receptors.

A. Classes of ligand-dependent NRs. NRs are subdivided into subfamilies in terms of their partnership, e.g. homodimer (Type-I NRs), and RXR heterodimer (Type-II NRs). B. Functional domains of the NR superfamily. Total number of amino acids (a. a.) and the ligand for each receptor are shown on the right. The receptors are specific for estrogens (ER), androgens (AR), glucocorticoids (GR), thyroid hormone (TR), vitamin D (VDR), fatty acid metabolite (PPAR), and retinoic acid derivatives (RAR, RXR).

structure alterations of the entire NR molecule following ligand binding remains largely unknown.

Nevertheless, it is hoped that an understanding of the molecular mechanisms that regulate AF- 1 and AF2 activities will facilitate the development of new therapies targeted to NRs, especially as it may be possible to minimize the risk of side effects of endogenous ligands through the development of synthetic ligands. For example, estrogen replacement therapy for postmenopausal women can cause adverse effects such as uterine bleeding, mastodynia, and weight gain, as well as increased risk of endometrial cancer, breast cancer, and coronary heart disease [60]. Thus, the development of a selective estrogen modulator (SERM) with beneficial effects on bone and the cardiovascular system, but without adverse effects on the uterine tract or mammary glands, would be highly desirable. For example, tamoxifen is a SERM originally designated as a pure estrogen antagonist in the treatment of estrogendependent breast cancer. However, it became obvious from clinical applications over 30 years that tamoxifen in fact served not only as an AF-1 agonist in bone, lipid metabolism, and the cardiovascular system, but also as an AF-2 antagonist in mammary glands and female reproductive organs [61]. Raloxifen, a SERM now marketed in Japan, has been reported to be very effective in improving osteoporosis in post-menopausal women $[62,63]$, but cannot prevent hot flashes. Thus, based on detailed knowledge of the mechanisms of $\mathrm{hER} \alpha \mathrm{AF}-1$ and AF-2 functions, it is anticipated that the desirable effects of SERMs can be further improved. 


\section{Decoding of Histone Signals and the Regulation of Gene Expression}

\section{A. Chromatin structure and histone modifications}

Each human cell contains approximately 2 meters of DNA. As DNA is acidic (i.e. negatively charged), chromatin structures are maintained in an electrically neutral state through association with histone proteins that are basic (i.e. positively charged). Two molecules of each of the four histone types (H2A, H2B, H3, and $\mathrm{H} 4)$ interact to form a histone octamer. DNA is coiled around this octamer, which forms a nucleosome, considered to be the minimum and basic structure of chromatin. One nucleosome subunit contains approximately 146 base pairs of DNA. However, not all DNA is coiled around histone octamers, as stretches of protein-free DNA serve as linker DNA between regions of coiled nucleosomal DNA. Repeated nucleosome units then form chromatin structures.

With regard to gene regulation, DNA regions contained within histone octamers are thought to be transcriptionally repressed. In contrast, linker DNA regions may play a leading role in gene activation, as these areas are easily accessible to transcription factors. To decode genetic information within the chromosome via transcription, it is now thought that histone octamers have to slide along the chromosomal DNA. However, the signals encoded on the chromosome that guide this process have long remained a mystery.

Recently, a revolutionary hypothesis was proposed that these chromatin signals are in fact related to posttranslational modifications on the histones. This breakthrough was based on observations from the crystal structure of the nucleosome, that the $\mathrm{N}$-terminal tails of histones extended out from the regions of coiled DNA (see Fig. 3) [64, 65]. It has since become clear that these histone N-terminal tails can be post-translationally modified by processes such as acetylation, deacetylation, methylation, phosphorylation, ubiquitination, and sumoylation, that are targeted to specific amino acid residues $[66,67]$. Furthermore, it has been shown biochemically that enzymes associated with these post-translational histone modifications exist as large protein complexes in the nucleus $[68,69]$. It appears that each histone octamer is uniquely modified according to different combinations of post-translational modifications. In other words, the nucleosome, long thought to have a relatively simple repetitive structure, may actually contain arrangements of modifications that reflect specific signals. Thus, the nucleosomal array may contain information on chromosomal position, such that the decoding of specific DNA sequences can only occur when certain chromosomal nucleosome arrays are reorganized.

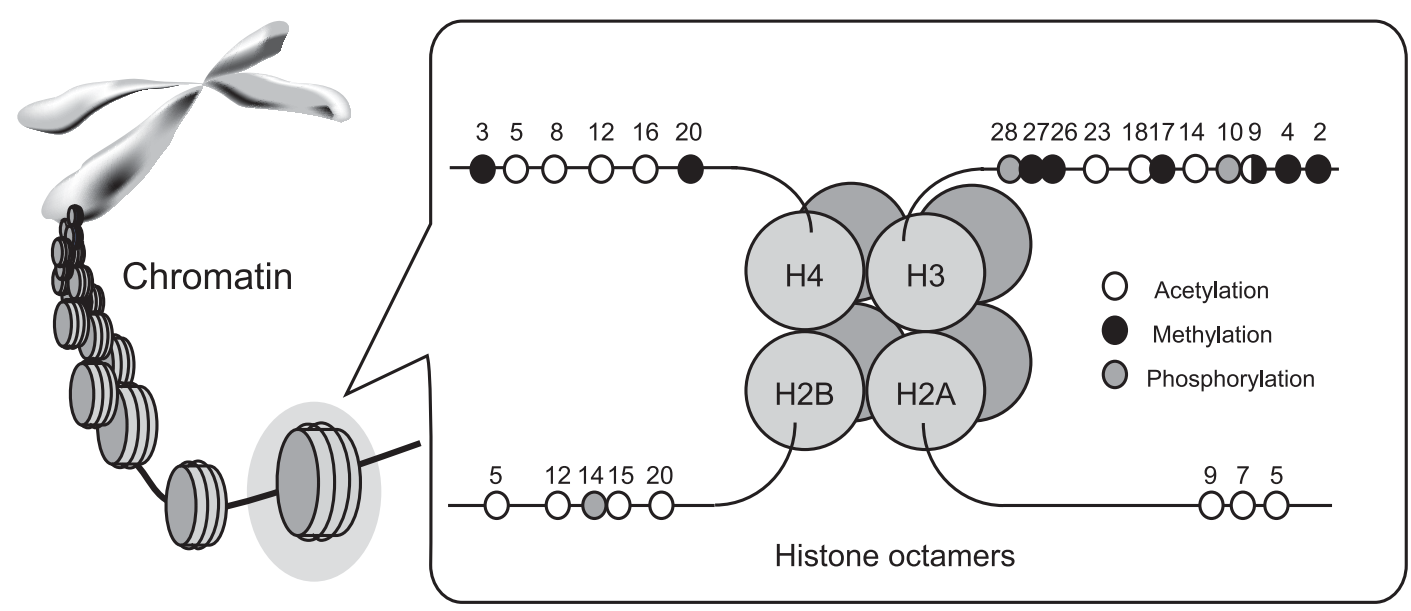

Fig. 3. Representative post-translational modifications of N-terminal tails of histones.

Chromatin is constituted with linker DNA and a nucleosome structure, which forms a complex between histone octamers surrounded by about 150 base pairs of DNA. N-terminal histone tails are protruded from the nucleosome core and are modified by several histone-modifying enzymes. Numerous combinations of post-translational histone modifications generates "histone code" to define the chromatin state and mark the addresses upon chromatin. 


\section{B. Chromatin remodeling}

ATP-dependent chromatin remodeling complexes are primarily responsible for the rearrangement of nucleosomal arrays, according to signals defined by histone modifications [70, 71]. The sliding of histone octamers, around which contacting DNA is coiled, is facilitated by ATP-dependent chromatin remodeling complexes, thereby exposing new naked DNA regions. Chromatin structures are also formed by ATP-depending chromatin remodeling complexes during DNA replication. Histone octamers are transferred to newly synthesized DNA by these complexes, and nucleosomal arrangements adjusted. Thus, chromatin remodeling factors and/or complexes play a major role in tertiary chromatin structure.

\section{Chromatin Regulation by NRs}

\section{A. Ligand-induced co-regulator switching by NRs}

Unliganded NRs are transcriptionally silent even when bound to specific DNA elements. Upon ligand binding, NR transactivation functions through AF-1 and AF-2 are induced together along with co-regulator switching (Fig. 4). Co-regulators that associate with unliganded or liganded NRs are classified into two

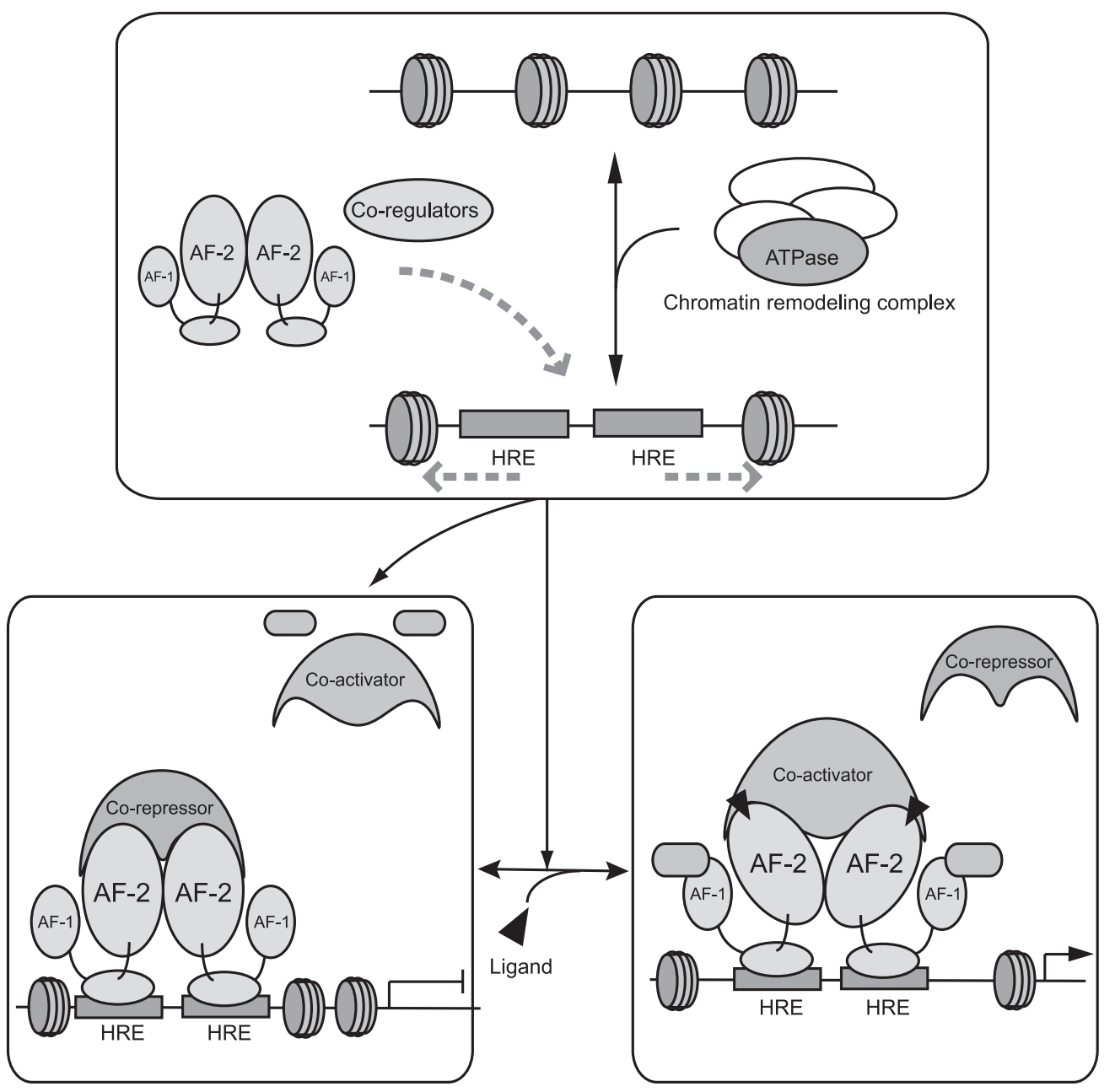

Fig. 4. Co-regulators support ligand-dependent transcriptional controls by NRs through chromatin remodeling and histone modifications.

Ligand binding positively and negatively controls gene expressions of target genes by NRs through switching of co-regulators; most of them form histone modifying enzyme complexes, together with histone remodeling by ATP-dependent chromatin remodeling complexes. 
functionally-opposite groups according to their impact on transactivation function. While co-repressors repress the transactivation function of unliganded NRs by physically associating with the LBD, particularly through $\alpha$-helix 12 , liganded NRs are co-activated by a number of co-activators through physical association with both the AF-1 and AF-2 domains. The switching between co-regulator classes is induced by ligand binding. Most co-regulators appear to form complexes, and their roles in gene regulation are most likely linked to histone modification and chromatin remodeling.

\section{B. Chromatin modifications by NRs}

Gene regulation is controlled by epigenetic modifications that define the chromatin state, mainly via histone modification. The best characterized of the histone modifications mediated by NRs is histone acetylation and deacetylation. Co-regulator complexes with histone acetyltransferase (HAT) activity activate the transcription of target genes through the acetylation of histones, while histone deacetyltransferase (HDAC) complexes deacetylate histones and serve as co-repressors for unliganded NRs. Histone methylation is also induced by co-regulator complexes that associate with NRs. The methylation of lysine at amino acid position 4 (K4) in histone $\mathrm{H} 3$ appears to induce an active state in chromatin that leads to transcriptional activation. In contrast, methylation of $\mathrm{K} 9$ in histone $\mathrm{H} 3$ is thought to lead to transcriptional suppression by inducing the adjacent chromosomal region to adopt an inactive state [72-75].

\section{Chromatin remodeling by ATP-dependent chromatin remodeling complexes and $N R s$}

ATP-dependent chromatin remodeling complexes use ATP hydrolysis to rearrange nucleosomal arrays in a non-covalent manner, thereby rendering chromosomal DNA accessible to DNA-binding transcription factors, including NRs (see Fig. 4). ATP-dependent chromatin remodeling complexes with distinct subunit combinations are classified into three major complex types (SWI/SNF, ISWI, and Mi-2) according to the ATPase that forms the main component of the complex [70]. Some of these complexes are known to physically associate with NRs [76-79]. For example, WINAC, a human multi-protein complex that directly interacts with VDR through the Williams syndrome transcription factor (WSTF), exhibits ATP-dependent chromatin remodeling activity, and contains both SWI/ SNF components and DNA replication-related factors. WSTF is highly homologous to hACF1, which together with hSNF2h are involved in the formation of well-characterized ISWI-based chromatin remodeling complexes. While WINAC mediates the recruitment of VDR to target gene promoters in the absence of ligand, the subsequent binding of co-activators to VDR requires ligand binding (Fig. 5) [80]. WINAC dysfunction seems to be at least partly responsible for some of the phenotypes associated with Williams syndrome, a rare autosomal dominant hereditary disorder with multiple symptoms, typically including congenital vascular lesions, elfin face, mental retardation, growth deficiency, and transient appearance of infantile aberrant vitamin D metabolism, including hypercalcemia [79]. Although some of the biological roles of ATP-dependent chromatin remodeling factors remain to be investigated, defects or mutations in Ini1, $\mathrm{hBrg} 1$, or $\mathrm{hBrm}$, which are subunits of the SWI/SNF type ATP-dependent chromatin remodeling complex subtype, have been found in several cancers [81-85]. Furthermore, an SWI2/SNF2-like ATPase motif is present in ATRX, a protein produced by a causative gene for myelodysplasia associated with $\alpha$-thalassemia (ATMDS) [86], and an SNF2-like domain is present in SMARCAL1, a protein that when defective leads to Schimke immuno-osseous dysplasia [87]. Hence, upon confirmation that these factors do act as chromatin remodelers, their related syndromes could be referred to as "chromatin remodeling factor diseases", and therefore considered as part of the "co-regulator disease" category. As chromatin remodeling is an essential step in gene regulation, ATP-dependent chromatin remodeling complexes presumably directly and indirectly support the ligand-induced transactivation of NRs. However, the functional interplay between NRs and chromatin modifying enzyme complexes remains to be clarified.

\section{NR Co-regulators and Co-regulator Complexes}

\section{A. NR AF-2 co-activators}

It is well understood that ligand-induced transcriptional activation by NRs consists of two activation 


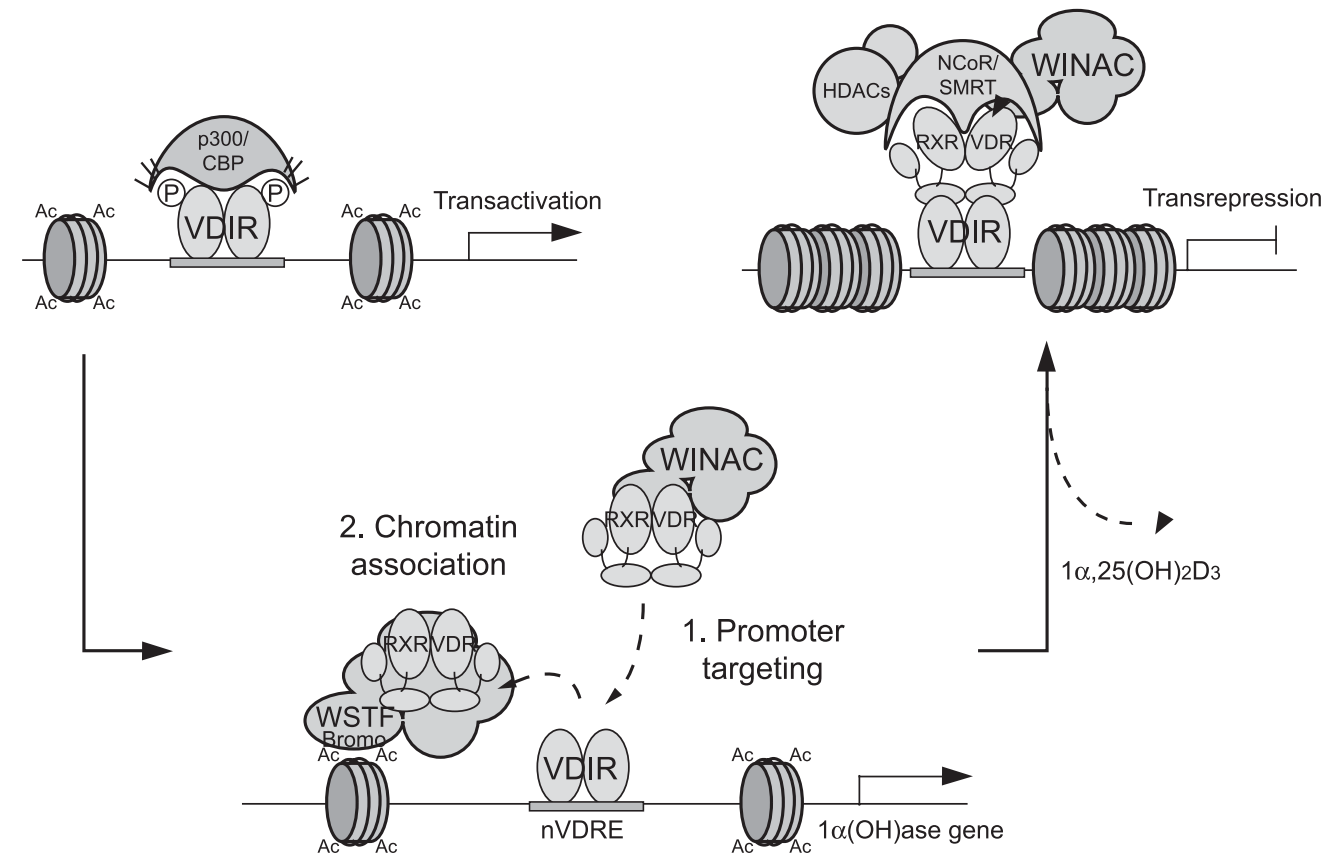

Fig. 5. Ligand-induced transrepression by VDR mediates functions of a novel chromatin remodeling complex (WINAC) and coregulator complexes of histone modifying enzymes in the gene promoter of a vitamin D biosynthesis enzyme $[1 \alpha(\mathrm{OH})$ ase $]$.

steps $[88,89]$. The first step is coupled with histone modifications such as acetylation, and is then followed by the formation of multi-complexes with general transcription factors that constitute a transcription initiation complex. Two such complexes, the p160/p300 HAT complex and the DRIP/TRAP complex, have been well characterized. Some components of these complexes have been shown to bind to liganded NR AF-2 domains through consensus LXXLL and related motifs present on some components [90]. p160/p300 complexes harbor one of three p160 family members (SRC-1 [91], TIF2/GRIP-1/SRC-2 [92, 93], pCIP/ RAC3/ACTR/AIB1/TRAM-1/SRC-3 [94-98]) and $\mathrm{CBP} / \mathrm{p} 300$ [99]. All these components are in fact HAT proteins presumably required by NRs either as single factors or, more likely, as multisubunit complexes with other components in a ligand-dependent manner. HAT activity facilitates transcription by loosening chromatin structures through the acetylation of histone $\mathrm{N}$-terminal tails.

SRC-1, one of the three p160 protein family members, contains three LXXLL motifs essential for ligand-dependent binding to NR AF-2 domains. SRC1 has been shown to assemble with CARM1, an enzyme with dual histone methyltransferase $[100,101]$ and HAT activities [102]. From structural analyses, it appears that SRC-1 binds to a groove formed by NR $\alpha$-helixes $3,4,5$, and 12 via the LXXLL motifs upon ligand binding. However, the three SRC-1 LXXLL motifs are not equivalent with respect to NR interactions. Altered amino acid sequences around the LXXLL motifs demonstrated altered NR interaction efficiencies dependent on the NR being used, which suggested that amino acids around the LXXLL motifs are essential for recognition and specific interactions with liganded NRs.

p300 was originally identified as a protein that bound adenovirus E1A [103], while the p300-related CBP protein was initially characterized as a co-activator of cAMP responsive element binding protein (CREB), a transcription factor activated by cAMP signaling [104]. CBP is thought to be the causative gene for the developmental disorder Rubinstein-Taybi syndrome characterized by multiple abnormalities, including broad thumbs and halluces, mental retardation, growth retardation, developmental delay, microcephaly, and craniofacial abnormalities [105]. p300/CBP exhibit high structural homology to each other, and are ubiquitously expressed in a variety of cells and tissues. It is likely that $\mathrm{p} 300 / \mathrm{CBP}$ bind to other classes of DNAbinding transcriptional factors in addition to NRs, functioning as common co-activators for these factors 
[106-109]. Although p300/CBP physically bind in a ligand-dependent manner to NR AF-2 domains to activate transcription [110], they also function as coactivators for AF-1 [58], which suggests that the p300/CBP co-activators bridge AF-1 and AF-2.

Many other co-activators have been identified that may be important in NR functions. PGC-1 was initially described as a PPAR $\gamma$ co-activator [111], and reported to dock with p160 member co-activators to NRs. PGC-1 has more recently been shown to be important for energy homeostasis. Indeed, a single nucleotide polymorphism (SNP) of the PGC-1 gene (Gly482Ser) is associated with the conversion from impaired glucose tolerance to Type II diabetes [112, 113]. Other NR co-activators include PRIP/ASC-2/ AIB3/RAP250/NRC that contains a single LXXLL motif and may act as a bridging factor between p300/ CBP and DRIP130, as well as being a component of the DRIP complex. Interestingly, its gene is known to be amplified in breast cancer [114-117]. Another example is GT-198. While its gene is localized to a breast cancer susceptibility locus, GT-198 protein exhibits kinase activity and acts as a tissue-specific NR co-activator through interaction with NR DNA-binding domains [118]. Hydrogen peroxide-inducible clone-5 (Hic-5), which belongs to the group III LIM domain protein family, contains four carboxyl-terminal LIM domains (LIM1-LIM4) and acts in the nucleus as a co-activator for steroid hormone receptors such as GR and AR $[119,120]$.

Following histone modification and chromatin remodeling, a mediator-like complex that forms a bridge between the NR-associated histone modifying complexes and the RNA polymerase II/transcription initiation complex is believed to be recruited to NRs. One such mediator-like complex is the DRIP/TRAP complex. This complex appears to contain no HAT activity, and was identified independently by two groups as a protein complex that interacted with VDR and TR $\alpha$ in a ligand-dependent manner [121, 122]. The DRIP/ TRAP complex enhances the transcriptional activity of NRs on naked DNA templates in cell-free, liganddependent transcription assays [123, 124], and also appears to activate transcription mediated by several transcriptional factor classes in addition to NRs. The complex component DRIP205/TRAP220 exhibits ligand-dependent binding to NRs via two LXXLL motifs, NR1 and NR2 [125]. In the presence of thyroid hormone, the TR-RXR heterodimer recruits the DRIP/
TRAP complex through the binding of RXR and TR to the NR1 and NR2 motifs, respectively. Mice heterozygous for a defective TRAP220 gene display pituitary hypothyroidism, whereas humans with TRAP230 abnormalities develop hypothyroidism [126]. Such conditions might also be classified as "co-regulator diseases" as might Rubinstein-Taybi syndrome that is caused by abnormal CBP function [105].

It is noteworthy that a third class of NR co-activator complex, the TFTC-type HAT complex, has also been identified [127]. This co-activator complex class harbors HAT activity, like p160/p300 complexes, but functionally resembles the DRIP/TRAP complex as a mediator complex. The TFTC-type HAT complex contains GCN5 HAT, the c-Myc interacting protein TRRAP/PAF400, and TAFII30, which are common factors shared with HAT complex subclass members including hTFTC, hPCAF, and hSTAGA HAT coactivator complexes. Three LXXLL motifs located in the central region of the TRRAP protein serve as the direct ligand-dependent surface for several NRs, including ER $\alpha$. Surprisingly, antisense mRNA molecules for TRRAP inhibit the estrogen-dependent cell growth of breast cancer cells, which indicates that TRRAP might represent a new therapeutic target in the treatment of estrogen-dependent breast cancer $[126,127]$.

\section{B. AF-1 co-activators of NRs}

While the above factors and complexes act as NR AF-2 co-activators, a number of NR AF-1 co-activators have also been documented. Amino acid sequences of NR A/B domains, which contain AF-1 activity, vary among NRs, which suggests that tissue-specific AF-1 functions of particular NRs are supported by unique co-activators. For instance, ER $\alpha$ is phosphorylated by mitogen-activated protein (MAP) kinase activated by growth factor signaling. This phosphorylation occurs at the serine residue at position 118 in the $\mathrm{A} / \mathrm{B}$ domain, and potentiates $\mathrm{hER} \alpha \mathrm{AF}-1$ function [128]. DEAD box helicases p68 and p72 form a p160/ p300 co-activator complex with the RNA co-activator SRA. This complex appears to bind more strongly to phosphorylated than non-phosphorylated ER $\alpha$ A/B domains, and serves as an ER $\alpha \mathrm{AF}-1$ co-activator $[129,130]$. Thus, $p 68$ and p72 AF-1 co-activators may mediate cross-talk between the growth factor and estrogen signaling pathways. Besides p68/p72, an RNA 
splicing complex also appears to be preferentially recruited to phosphorylated $\operatorname{Ser}^{118}$ in hER $\alpha$ [131]. In this case, the hER $\alpha$ AF-1 domain appears to also serve as an interacting domain for the activated dioxin receptor (AhR), establishing another potential cross-talk between estrogen- and AhR-mediated signals [132]. "Co-regulator diseases" due to AF-1 co-activators abnormalities have also been reported, such as defects in an AR-specific AF1 co-activator that results in Tfm [133], and mice genetically deficient in Cnot 7 (CAF1), an AF-1 co-activator of retinoid X receptor (RXR) $\beta$, have recently been reported to exhibit oligoasetheno-teratozoospermia [134].

\section{Co-repressors of NRs}

Generally, NRs activate the transcription of target genes through the recruitment of co-activators in a ligand-dependent manner, while in the absence of ligand NRs suppress transcription by recruiting corepressors. These co-repressors can include histone modifying complexes such as the NR-co-repressor $(\mathrm{N}-\mathrm{CoR})$ and silencing mediator for retinoic acid receptor and thyroid hormone receptor (SMRT) complexes [135-137]. NCoR and SMRT complexes share a number of proteins such as HDAC $1 / 2 / 3$, the Mad presumptive co-repressor $\mathrm{mSin} 3$, and transducin (beta)-like (TBL) 1, and a WD-40 repeat-containing protein, the gene for which was found to be mutated in human sensorineural deafness [138-142]. These co-repressor complexes deacetylate the $\mathrm{N}$-terminal tails of histones, thereby "locking" the chromatin structure, leading to suppression of target gene transcription.

TBL1 and the homologous TBLR1 are thought to serve as factors that exchange co-repressors for coactivators. The ubiquitin/proteasome system includes the $26 \mathrm{~S}$ proteasome, a complex composed of a $20 \mathrm{~S}$ catalytic core involved in protein proteolysis and two ATPase-containing 19S regulatory particles that recognize polyubiquitin-tagged substrates [143]. TBL1 and TBLR1 are thought to function as adaptors for the recruitment of ubiquitin/19S proteasome complexes, thereby mediating the proteasomal degradation of corepressors, and inducing the recruitment of coactivators [144].

The mechanisms of transcriptional repression by nuclear orphan receptors remain largely unknown.
However, it has been reported that the nuclear orphan receptor chicken ovalbumin upstream promoter-transcription factors (COUP-TF) I represses the transcriptional activity of target genes that interact with $\mathrm{NCoR}$ and SMRT [145]. Another nuclear orphan receptor, PNR, which is the causative gene for enhanced S-cone syndrome, acts as a sequence-specific repressor that controls neuronal differentiation in the developing retina. A PNR co-repressor complex has been identified that includes E2F/Myb-associated proteins, NCoR/ HDAC complex-related components, TBL3 (part of the same protein family as TBL1), and the DEVH-box co-repressor (Dev-CoR) that belongs to the DEAD/ DEVH protein family. This co-repressor directly interacts with PNR and functions as a platform protein. Notably, the PNR-associated Dev-CoR complex appears to function as a negative cell cycle repressor via inhibition of cell cycle-related gene promoters, indicating that co-repressors may have similar biological importance as co-activators in gene regulation (S. T., H. K., S. K., unpublished results).

\section{Perspectives}

NRs require a number of distinct classes of factors and/or complexes for their ligand-independent and -dependent functions in gene regulation. From the most current views on the molecular mechanisms of gene regulation by DNA-binding transcription factors, it appears that a number of complexes and factors associate with a given transcription factor in a sequential and highly regulated manner. However, while NRs appear to recruit a number of factors/complexes, it is still unclear whether particular NR molecules require many factors/complexes or only limited numbers of factors/complexes depending on the promoter/chromatin context. Also, it is likely to become clear in the near future how many of the numerous diseases and pathophysiologies related to NR functions are linked to malfunctions within co-regulators or co-regulator complexes. Such advances in the understanding of molecular mechanisms that underlie NR function in a variety of physiological and pathophysiological situations will contribute to drug discovery and new clinical applications. 


\section{References}

1. Akhmedov NB, Piriev NI, Chang B, Rapoport AL, Hawes NL, Nishina PM, Nusinowitz S, Heckenlively JR, Roderick TH, Kozak CA, Danciger M, Davisson MT, Farber DB (2000) A deletion in a photoreceptorspecific nuclear receptor mRNA causes retinal degeneration in the rd7 mouse. Proc Natl Acad Sci USA 97: 5551-5556.

2. Alberti S, Schuster G, Parini P, Feltkamp D, Diczfalusy U, Rudling M, Angelin B, Bjorkhem I, Pettersson S, Gustafsson JA (2001) Hepatic cholesterol metabolism and resistance to dietary cholesterol in LXRbeta-deficient mice. J Clin Invest 107: 565-573.

3. Andre E, Conquet F, Steinmayr M, Stratton SC, Porciatti V, Becker-Andre M (1998) Disruption of retinoid-related orphan receptor beta changes circadian behavior, causes retinal degeneration and leads to vacillans phenotype in mice. Embo $J$ 17: 3867-3877.

4. Berger S, Bleich M, Schmid W, Cole TJ, Peters J, Watanabe H, Kriz W, Warth R, Greger R, Schutz G (1998) Mineralocorticoid receptor knockout mice: pathophysiology of $\mathrm{Na}+$ metabolism. Proc Natl Acad Sci USA 95: 9424-9429.

5. Brown NS, Smart A, Sharma V, Brinkmeier ML, Greenlee L, Camper SA, Jensen DR, Eckel RH, Krezel W, Chambon P, Haugen BR (2000) Thyroid hormone resistance and increased metabolic rate in the RXRgamma-deficient mouse. J Clin Invest 106: 73-79.

6. Chen WS, Manova K, Weinstein DC, Duncan SA, Plump AS, Prezioso VR, Bachvarova RF, Darnell JE Jr (1994) Disruption of the HNF-4 gene, expressed in visceral endoderm, leads to cell death in embryonic ectoderm and impaired gastrulation of mouse embryos. Genes Dev 8: 2466-2477.

7. Forrest D, Erway LC, Ng L, Altschuler R, Curran T (1996) Thyroid hormone receptor beta is essential for development of auditory function. Nat Genet 13: 354357.

8. Forrest D, Hanebuth E, Smeyne RJ, Everds N, Stewart CL, Wehner JM, Curran T (1996) Recessive resistance to thyroid hormone in mice lacking thyroid hormone receptor beta: evidence for tissue-specific modulation of receptor function. Embo J 15: 3006-3015.

9. Gauthier K, Plateroti M, Harvey CB, Williams GR, Weiss RE, Refetoff S, Willott JF, Sundin V, Roux JP, Malaval L, Hara M, Samarut J, Chassande O (2001) Genetic analysis reveals different functions for the products of the thyroid hormone receptor alpha locus. Mol Cell Biol 21: 4748-4760.

10. Gold DA, Baek SH, Schork NJ, Rose DW, Larsen DD, Sachs BD, Rosenfeld MG, Hamilton BA (2003) RORalpha coordinates reciprocal signaling in cerebellar development through sonic hedgehog and calciumdependent pathways. Neuron 40: 1119-1131.

11. Haugen BR, Jensen DR, Sharma V, Pulawa LK, Hays WR, Krezel W, Chambon P, Eckel RH (2004) Retinoid
$\mathrm{X}$ receptor gamma-deficient mice have increased skeletal muscle lipoprotein lipase activity and less weight gain when fed a high-fat diet. Endocrinology 145: 3679-3685.

12. Hess RA, Bunick D, Lee KH, Bahr J, Taylor JA, Korach KS, Lubahn DB (1997) A role for oestrogens in the male reproductive system. Nature 390: 509-512.

13. Kastner P, Grondona JM, Mark M, Gansmuller A, LeMeur M, Decimo D, Vonesch JL, Dolle P, Chambon P (1994) Genetic analysis of RXR alpha developmental function: convergence of RXR and RAR signaling pathways in heart and eye morphogenesis. Cell 78: 987-1003.

14. Kastner P, Mark M, Chambon P (1995) Nonsteroid nuclear receptors: what are genetic studies telling us about their role in real life? Cell 83: 859-869.

15. Kastner P, Mark M, Leid M, Gansmuller A, Chin W, Grondona JM, Decimo D, Krezel W, Dierich A, Chambon P (1996) Abnormal spermatogenesis in RXR beta mutant mice. Genes Dev 10: 80-92.

16. Kawano H, Sato T, Yamada T, Matsumoto T, Sekine K, Watanabe T, Nakamura T, Fukuda T, Yoshimura K, Yoshizawa T, Aihara K, Yamamoto Y, Nakamichi Y, Metzger D, Chambon P, Nakamura K, Kawaguchi H, Kato S (2003) Suppressive function of androgen receptor in bone resorption. Proc Natl Acad Sci USA 100: 9416-9421.

17. Kersten S, Seydoux J, Peters JM, Gonzalez FJ, Desvergne B, Wahli W (1999) Peroxisome proliferatoractivated receptor alpha mediates the adaptive response to fasting. J Clin Invest 103: 1489-1498.

18. Kliewer SA, Goodwin B, Willson TM (2002) The nuclear pregnane $\mathrm{X}$ receptor: a key regulator of xenobiotic metabolism. Endocr Rev 23: 687-702.

19. Krege JH, Hodgin JB, Couse JF, Enmark E, Warner M, Mahler JF, Sar M, Korach KS, Gustafsson JA, Smithies O (1998) Generation and reproductive phenotypes of mice lacking estrogen receptor beta. Proc Natl Acad Sci USA 95: 15677-15682.

20. Lee SS, Pineau T, Drago J, Lee EJ, Owens JW, Kroetz DL, Fernandez-Salguero PM, Westphal H, Gonzalez FJ (1995) Targeted disruption of the alpha isoform of the peroxisome proliferator-activated receptor gene in mice results in abolishment of the pleiotropic effects of peroxisome proliferators. Mol Cell Biol 15: 3012 3022 .

21. Lohnes D, Kastner P, Dierich A, Mark M, LeMeur M, Chambon P (1993) Function of retinoic acid receptor gamma in the mouse. Cell 73: 643-658.

22. Lubahn DB, Moyer JS, Golding TS, Couse JF, Korach KS, Smithies O (1993) Alteration of reproductive function but not prenatal sexual development after insertional disruption of the mouse estrogen receptor gene. Proc Natl Acad Sci USA 90: 11162-11166.

23. Lufkin T, Lohnes D, Mark M, Dierich A, Gorry P, 
Gaub MP, LeMeur M, Chambon P (1993) High postnatal lethality and testis degeneration in retinoic acid receptor alpha mutant mice. Proc Natl Acad Sci USA 90: 7225-7229.

24. Luo X, Ikeda Y, Parker KL (1994) A cell-specific nuclear receptor is essential for adrenal and gonadal development and sexual differentiation. Cell 77: 481490.

25. Lydon JP, DeMayo FJ, Funk CR, Mani SK, Hughes AR, Montgomery CA Jr, Shyamala G, Conneely OM, O’Malley BW (1995) Mice lacking progesterone receptor exhibit pleiotropic reproductive abnormalities. Genes Dev 9: 2266-2278.

26. Monaghan AP, Bock D, Gass P, Schwager A, Wolfer DP, Lipp HP, Schutz G (1997) Defective limbic system in mice lacking the tailless gene. Nature 390: 515-517.

27. Morohashi K, Tsuboi-Asai H, Matsushita S, Suda M, Nakashima M, Sasano H, Hataba Y, Li CL, Fukata J, Irie J, Watanabe T, Nagura H, Li E (1999) Structural and functional abnormalities in the spleen of an mFtzF1 gene-disrupted mouse. Blood 93: 1586-1594.

28. Peet DJ, Turley SD, Ma W, Janowski BA, Lobaccaro JM, Hammer RE, Mangelsdorf DJ (1998) Cholesterol and bile acid metabolism are impaired in mice lacking the nuclear oxysterol receptor LXR alpha. Cell 93: 693-704.

29. Pereira FA, Qiu Y, Zhou G, Tsai MJ, Tsai SY (1999) The orphan nuclear receptor COUP-TFII is required for angiogenesis and heart development. Genes Dev 13: 1037-1049.

30. Peters JM, Lee SS, Li W, Ward JM, Gavrilova O, Everett C, Reitman ML, Hudson LD, Gonzalez FJ (2000) Growth, adipose, brain, and skin alterations resulting from targeted disruption of the mouse peroxisome proliferator-activated receptor beta(delta). Mol Cell Biol 20: 5119-5128.

31. Qiu Y, Pereira FA, DeMayo FJ, Lydon JP, Tsai SY, Tsai MJ (1997) Null mutation of mCOUP-TFI results in defects in morphogenesis of the glossopharyngeal ganglion, axonal projection, and arborization. Genes Dev 11: 1925-1937.

32. Sato T, Matsumoto T, Kawano H, Watanabe T, Uematsu Y, Sekine K, Fukuda T, Aihara K, Krust A, Yamada T, Nakamichi Y, Yamamoto Y, Nakamura T, Yoshimura $\mathrm{K}$, Yoshizawa T, Metzger D, Chambon P, Kato S (2004) Brain masculinization requires androgen receptor function. Proc Natl Acad Sci USA 101: 1673-1678.

33. Schmid W, Cole TJ, Blendy JA, Schutz G (1995) Molecular genetic analysis of glucocorticoid signalling in development. J Steroid Biochem Mol Biol 53: 33-35.

34. Sinal CJ, Tohkin M, Miyata M, Ward JM, Lambert G, Gonzalez FJ (2000) Targeted disruption of the nuclear receptor FXR/BAR impairs bile acid and lipid homeostasis. Cell 102: 731-744.

35. Sun Z, Unutmaz D, Zou YR, Sunshine MJ, Pierani A, Brenner-Morton S, Mebius RE, Littman DR (2000) Requirement for RORgamma in thymocyte survival and lymphoid organ development. Science 288: 2369 2373.

36. Yoshizawa T, Handa Y, Uematsu Y, Takeda S, Sekine K, Yoshihara Y, Kawakami T, Arioka K, Sato H, Uchiyama Y, Masushige S, Fukamizu A, Matsumoto T, Kato S (1997) Mice lacking the vitamin D receptor exhibit impaired bone formation, uterine hypoplasia and growth retardation after weaning. Nat Genet 16 : 391-396.

37. Yu RT, McKeown M, Evans RM, Umesono K (1994) Relationship between Drosophila gap gene tailless and a vertebrate nuclear receptor Tlx. Nature 370: 375-379.

38. Kubota N, Terauchi Y, Miki H, Tamemoto H, Yamauchi T, Komeda K, Satoh S, Nakano R, Ishii C, Sugiyama T, Eto K, Tsubamoto Y, Okuno A, Murakami K, Sekihara H, Hasegawa G, Naito M, Toyoshima Y, Tanaka S, Shiota K, Kitamura T, Fujita T, Ezaki O, Aizawa S, Kadowaki T, et al. (1999) PPAR gamma mediates high-fat diet-induced adipocyte hypertrophy and insulin resistance. Mol Cell 4: 597-609.

39. Knouff C, Auwerx J (2004) Peroxisome proliferatoractivated receptor-gamma calls for activation in moderation: lessons from genetics and pharmacology. Endocr Rev 25: 899-918.

40. Vu-Dac N, Schoonjans K, Kosykh V, Dallongeville J, Fruchart JC, Staels B, Auwerx J (1995) Fibrates increase human apolipoprotein A-II expression through activation of the peroxisome proliferator-activated receptor. J Clin Invest 96: 741-750.

41. Forman BM, Chen J, Evans RM (1997) Hypolipidemic drugs, polyunsaturated fatty acids, and eicosanoids are ligands for peroxisome proliferator-activated receptors alpha and delta. Proc Natl Acad Sci USA 94: 43124317.

42. Bocher V, Pineda-Torra I, Fruchart JC, Staels B (2002) PPARs: transcription factors controlling lipid and lipoprotein metabolism. Ann NY Acad Sci 967: 7-18.

43. Osborne CK (1998) Tamoxifen in the treatment of breast cancer. N Engl J Med 339: 1609-1618.

44. Herynk MH, Fuqua SA (2004) Estrogen receptor mutations in human disease. Endocr Rev 25: 869-898.

45. Catalona WJ (1994) Management of cancer of the prostate. N Engl J Med 331: 996-1004.

46. Griffin JE (1992) Androgen resistance - the clinical and molecular spectrum. $N$ Engl J Med 326: 611-618.

47. Takeyama $\mathrm{K}$, Ito $\mathrm{S}$, Yamamoto $\mathrm{A}$, Tanimoto $\mathrm{H}$, Furutani T, Kanuka H, Miura M, Tabata T, Kato S (2002) Androgen-dependent neurodegeneration by polyglutamine-expanded human androgen receptor in Drosophila. Neuron 35: 855-864.

48. Malloy PJ, Feldman D (2003) Hereditary 1,25Dihydroxyvitamin D-resistant rickets. Endocr Dev 6 : 175-199.

49. Yen PM (2003) Molecular basis of resistance to thyroid hormone. Trends Endocrinol Metab 14: 327-333.

50. Yamagata K, Furuta H, Oda N, Kaisaki PJ, Menzel S, Cox NJ, Fajans SS, Signorini S, Stoffel M, Bell GI 
(1996) Mutations in the hepatocyte nuclear factor4alpha gene in maturity-onset diabetes of the young (MODY1). Nature 384: 458-460.

51. Haider NB, Jacobson SG, Cideciyan AV, Swiderski R, Streb LM, Searby C, Beck G, Hockey R, Hanna DB, Gorman S, Duhl D, Carmi R, Bennett J, Weleber RG, Fishman GA, Wright AF, Stone EM, Sheffield VC (2000) Mutation of a nuclear receptor gene, NR2E3, causes enhanced $\mathrm{S}$ cone syndrome, a disorder of retinal cell fate. Nat Genet 24: 127-131.

52. Mangelsdorf DJ, Thummel C, Beato M, Herrlich $\mathrm{P}$, Schutz G, Umesono K, Blumberg B, Kastner P, Mark M, Chambon P, Evans RM (1995) The nuclear receptor superfamily: the second decade. Cell 83: 835-839.

53. Carson-Jurica MA, Schrader WT, O'Malley BW (1990) Steroid receptor family: structure and functions. Endocr Rev 11: 201-220.

54. Ylikomi T, Bocquel MT, Berry M, Gronemeyer H, Chambon P (1992) Cooperation of proto-signals for nuclear accumulation of estrogen and progesterone receptors. EMBO J 11: 3681-3694.

55. Tasset D, Tora L, Fromental C, Scheer E, Chambon P (1990) Distinct classes of transcriptional activating domains function by different mechanisms. Cell 62: 1177-1187.

56. Shiau AK, Barstad D, Radek JT, Meyers MJ, Nettles KW, Katzenellenbogen BS, Katzenellenbogen JA, Agard DA, Greene GL (2002) Structural characterization of a subtype-selective ligand reveals a novel mode of estrogen receptor antagonism. Nat Struct Biol 9: 359-364.

57. Wu YL, Yang X, Ren Z, McDonnell DP, Norris JD, Willson TM, Greene GL (2005) Structural basis for an unexpected mode of SERM-mediated ER antagonism. Mol Cell 18: 413-424.

58. Kobayashi Y, Kitamoto T, Masuhiro Y, Watanabe M, Kase T, Metzger D, Yanagisawa J, Kato S (2000) p300 mediates functional synergism between AF-1 and AF-2 of estrogen receptor alpha and beta by interacting directly with the $\mathrm{N}$-terminal A/B domains. J Biol Chem 275: 15645-15651.

59. McInerney EM, Tsai MJ, O’Malley BW, Katzenellenbogen BS (1996) Analysis of estrogen receptor transcriptional enhancement by a nuclear hormone receptor coactivator. Proc Natl Acad Sci USA 93: 10069-10073.

60. Manson JE, Hsia J, Johnson KC, Rossouw JE, Assaf AR, Lasser NL, Trevisan M, Black HR, Heckbert SR, Detrano R, Strickland OL, Wong ND, Crouse JR, Stein E, Cushman M (2003) Estrogen plus progestin and the risk of coronary heart disease. $N$ Engl J Med 349: 523534.

61. Riggs BL, Hartmann LC (2003) Selective estrogenreceptor modulators - mechanisms of action and application to clinical practice. $N$ Engl J Med 348: 618-629.

62. Bryant HU (2001) Mechanism of action and preclinical profile of raloxifene, a selective estrogen receptor mod- ulation. Rev Endocr Metab Disord 2: 129-138.

63. Draper MW (2003) The role of selective estrogen receptor modulators (SERMs) in postmenopausal health. Ann NY Acad Sci 997: 373-377.

64. Luger K, Mader AW, Richmond RK, Sargent DF, Richmond TJ (1997) Crystal structure of the nucleosome core particle at 2.8 A resolution. Nature 389: 251-260.

65. Rea S, Eisenhaber F, O'Carroll D, Strahl BD, Sun ZW, Schmid M, Opravil S, Mechtler K, Ponting CP, Allis CD, Jenuwein T (2000) Regulation of chromatin structure by site-specific histone $\mathrm{H} 3$ methyltransferases. Nature 406: 593-599.

66. Jenuwein T, Allis CD (2001) Translating the histone code. Science 293: 1074-1080.

67. Fischle W, Wang Y, Allis CD (2003) Binary switches and modification cassettes in histone biology and beyond. Nature 425: 475-479.

68. McKenna NJ, O’Malley BW (2002) Combinatorial control of gene expression by nuclear receptors and coregulators. Cell 108: 465-474.

69. Rachez C, Lemon BD, Suldan Z, Bromleigh V, Gamble M, Naar AM, Erdjument-Bromage H, Tempst P, Freedman LP (1999) Ligand-dependent transcription activation by nuclear receptors requires the DRIP complex. Nature 398: 824-828.

70. Narlikar GJ, Fan HY, Kingston RE (2002) Cooperation between complexes that regulate chromatin structure and transcription. Cell 108: 475-487.

71. Belotserkovskaya R, Oh S, Bondarenko VA, Orphanides G, Studitsky VM, Reinberg D (2003) FACT facilitates transcription-dependent nucleosome alteration. Science 301: 1090-1093.

72. Noma K, Allis CD, Grewal SI (2001) Transitions in distinct histone $\mathrm{H} 3$ methylation patterns at the heterochromatin domain boundaries. Science 293: 1150-1155.

73. Litt MD, Simpson M, Gaszner M, Allis CD, Felsenfeld G (2001) Correlation between histone lysine methylation and developmental changes at the chicken betaglobin locus. Science 293: 2453-2455.

74. Saccani S, Natoli G (2002) Dynamic changes in histone H3 Lys 9 methylation occurring at tightly regulated inducible inflammatory genes. Genes Dev 16: 2219 2224.

75. Santos-Rosa H, Schneider R, Bannister AJ, Sherriff J, Bernstein BE, Emre NC, Schreiber SL, Mellor J, Kouzarides T (2002) Active genes are tri-methylated at K4 of histone H3. Nature 419: 407-411.

76. Nie Z, Xue Y, Yang D, Zhou S, Deroo BJ, Archer TK, Wang W (2000) A specificity and targeting subunit of a human SWI/SNF family-related chromatin-remodeling complex. Mol Cell Biol 20: 8879-8888.

77. DiRenzo J, Shang Y, Phelan M, Sif S, Myers M, Kingston R, Brown M (2000) BRG-1 is recruited to estrogen-responsive promoters and cooperates with factors involved in histone acetylation. Mol Cell Biol 20: 7541-7549. 
78. Belandia B, Orford RL, Hurst HC, Parker MG (2002) Targeting of SWI/SNF chromatin remodelling complexes to estrogen-responsive genes. EMBO J 21: 4094-4103.

79. Kitagawa H, Fujiki R, Yoshimura K, Mezaki Y, Uematsu Y, Matsui D, Ogawa S, Unno K, Okubo M, Tokita A, Nakagawa T, Ito T, Ishimi Y, Nagasawa H, Matsumoto T, Yanagisawa J, Kato S (2003) The chromatin-remodeling complex WINAC targets a nuclear receptor to promoters and is impaired in Williams syndrome. Cell 113: 905-917.

80. Fujiki R, Kim MS, Sasaki Y, Yoshimura K, Kitagawa $\mathrm{H}$, Kato $\mathrm{S}$ (in press.) Ligand-induced transrepression by VDR through association of WSTF with acetylated histones. EMBO J.

81. Versteege I, Sevenet N, Lange J, Rousseau-Merck MF, Ambros P, Handgretinger R, Aurias A, Delattre O (1998) Truncating mutations of hSNF5/INI1 in aggressive paediatric cancer. Nature 394: 203-206.

82. Guidi CJ, Sands AT, Zambrowicz BP, Turner TK, Demers DA, Webster W, Smith TW, Imbalzano AN, Jones SN (2001) Disruption of Inil leads to periimplantation lethality and tumorigenesis in mice. $\mathrm{Mol}$ Cell Biol 21: 3598-3603.

83. Roberts CW, Galusha SA, McMenamin ME, Fletcher CD, Orkin SH (2000) Haploinsufficiency of Snf5 (integrase interactor 1) predisposes to malignant rhabdoid tumors in mice. Proc Natl Acad Sci USA 97: 1379613800.

84. Bultman S, Gebuhr T, Yee D, La Mantia C, Nicholson J, Gilliam A, Randazzo F, Metzger D, Chambon P, Crabtree G, Magnuson T (2000) A Brg1 null mutation in the mouse reveals functional differences among mammalian SWI/SNF complexes. Mol Cell 6: 12871295.

85. Wong AK, Shanahan F, Chen Y, Lian L, Ha P, Hendricks K, Ghaffari S, Iliev D, Penn B, Woodland AM, Smith R, Salada G, Carillo A, Laity K, Gupte J, Swedlund B, Tavtigian SV, Teng DH, Lees E (2000) BRG1, a component of the SWI-SNF complex, is mutated in multiple human tumor cell lines. Cancer Res 60: 6171-6177.

86. Gibbons RJ, Pellagatti A, Garrick D, Wood WG, Malik N, Ayyub H, Langford C, Boultwood J, Wainscoat JS, Higgs DR (2003) Identification of acquired somatic mutations in the gene encoding chromatin-remodeling factor ATRX in the alpha-thalassemia myelodysplasia syndrome (ATMDS). Nat Genet 34: 446-449.

87. Boerkoel CF, Takashima H, John J, Yan J, Stankiewicz P, Rosenbarker L, Andre JL, Bogdanovic R, Burguet A, Cockfield S, Cordeiro I, Frund S, Illies F, Joseph M, Kaitila I, Lama G, Loirat C, McLeod DR, Milford DV, Petty EM, Rodrigo F, Saraiva JM, Schmidt B, Smith GC, Spranger J, Stein A, Thiele H, Tizard J, Weksberg R, Lupski JR, Stockton DW (2002) Mutant chromatin remodeling protein SMARCAL1 causes Schimke immuno-osseous dysplasia. Nat Genet 30: 215-220.
88. Freedman LP (1999) Increasing the complexity of coactivation in nuclear receptor signaling. Cell 97: 5-8.

89. Ito M, Roeder RG (2001) The TRAP/SMCC/Mediator complex and thyroid hormone receptor function. Trends Endocrinol Metab 12: 127-134.

90. Heery DM, Kalkhoven E, Hoare S, Parker MG (1997) A signature motif in transcriptional co-activators mediates binding to nuclear receptors. Nature 387: 733 736.

91. Onate SA, Tsai SY, Tsai MJ, O’Malley BW (1995) Sequence and characterization of a coactivator for the steroid hormone receptor superfamily. Science 270: 1354-1357.

92. Voegel JJ, Heine MJ, Zechel C, Chambon P, Gronemeyer $\mathrm{H}$ (1996) TIF2, a $160 \mathrm{kDa}$ transcriptional mediator for the ligand-dependent activation function AF-2 of nuclear receptors. EMBO J 15: 3667-3675.

93. Hong H, Kohli K, Trivedi A, Johnson DL, Stallcup MR (1996) GRIP1, a novel mouse protein that serves as a transcriptional coactivator in yeast for the hormone binding domains of steroid receptors. Proc Natl Acad Sci USA 93: 4948-4952.

94. Torchia J, Rose DW, Inostroza J, Kamei Y, Westin S, Glass CK, Rosenfeld MG (1997) The transcriptional co-activator $\mathrm{p} / \mathrm{CIP}$ binds CBP and mediates nuclearreceptor function. Nature 387: 677-684.

95. Anzick SL, Kononen J, Walker RL, Azorsa DO, Tanner MM, Guan XY, Sauter G, Kallioniemi OP, Trent JM, Meltzer PS (1997) AIB1, a steroid receptor coactivator amplified in breast and ovarian cancer. Science 277: 965-968.

96. Chen H, Lin RJ, Schiltz RL, Chakravarti D, Nash A, Nagy L, Privalsky ML, Nakatani Y, Evans RM (1997) Nuclear receptor coactivator ACTR is a novel histone acetyltransferase and forms a multimeric activation complex with $\mathrm{P} / \mathrm{CAF}$ and $\mathrm{CBP} / \mathrm{p} 300$. Cell 90: 569580.

97. Li H, Gomes PJ, Chen JD (1997) RAC3, a steroid/ nuclear receptor-associated coactivator that is related to SRC-1 and TIF2. Proc Natl Acad Sci USA 94: 84798484.

98. Takeshita A, Cardona GR, Koibuchi N, Suen CS, Chin WW (1997) TRAM-1, A novel 160-kDa thyroid hormone receptor activator molecule, exhibits distinct properties from steroid receptor coactivator-1. J Biol Chem 272: 27629-27634.

99. Ogryzko VV, Schiltz RL, Russanova V, Howard BH, Nakatani Y (1996) The transcriptional coactivators p300 and CBP are histone acetyltransferases. Cell 87: 953-959.

100. Chen D, Ma H, Hong H, Koh SS, Huang SM, Schurter BT, Aswad DW, Stallcup MR (1999) Regulation of transcription by a protein methyltransferase. Science 284: 2174-2177.

101. Kalkhoven E, Valentine JE, Heery DM, Parker MG (1998) Isoforms of steroid receptor co-activator 1 differ in their ability to potentiate transcription by the oestro- 
gen receptor. EMBO J 17: 232-243.

102. Spencer TE, Jenster G, Burcin MM, Allis CD, Zhou J, Mizzen CA, McKenna NJ, Onate SA, Tsai SY, Tsai MJ, O’Malley BW (1997) Steroid receptor coactivator1 is a histone acetyltransferase. Nature 389: 194-198.

103. Eckner R, Ewen ME, Newsome D, Gerdes M, DeCaprio JA, Lawrence JB, Livingston DM (1994) Molecular cloning and functional analysis of the adenovirus E1Aassociated $300-\mathrm{kD}$ protein (p300) reveals a protein with properties of a transcriptional adaptor. Genes Dev 8: 869-884.

104. Kwok RP, Lundblad JR, Chrivia JC, Richards JP, Bachinger HP, Brennan RG, Roberts SG, Green MR, Goodman RH (1994) Nuclear protein CBP is a coactivator for the transcription factor CREB. Nature 370: 223-226.

105. Petrij F, Giles RH, Dauwerse HG, Saris JJ, Hennekam $\mathrm{RC}$, Masuno M, Tommerup N, van Ommen GJ, Goodman RH, Peters DJ, et al. (1995) RubinsteinTaybi syndrome caused by mutations in the transcriptional co-activator CBP. Nature 376: 348-351.

106. Xu L, Lavinsky RM, Dasen JS, Flynn SE, McInerney EM, Mullen TM, Heinzel T, Szeto D, Korzus E, Kurokawa R, Aggarwal AK, Rose DW, Glass CK, Rosenfeld MG (1998) Signal-specific co-activator domain requirements for Pit-1 activation. Nature 395: 301-306.

107. Kishimoto M, Okimura Y, Yagita K, Iguchi G, Fumoto M, Iida K, Kaji H, Okamura H, Chihara K (2002) Novel function of the transactivation domain of a pituitary-specific transcription factor, Pit-1. J Biol Chem 277: 45141-45148.

108. Scolnick DM, Chehab NH, Stavridi ES, Lien MC, Caruso L, Moran E, Berger SL, Halazonetis TD (1997) CREB-binding protein and p300/CBP-associated factor are transcriptional coactivators of the p53 tumor suppressor protein. Cancer Res 57: 3693-3696.

109. Yuan W, Condorelli G, Caruso M, Felsani A, Giordano A (1996) Human p300 protein is a coactivator for the transcription factor MyoD. J Biol Chem 271: 90099013.

110. Kamei Y, Xu L, Heinzel T, Torchia J, Kurokawa R, Gloss B, Lin SC, Heyman RA, Rose DW, Glass CK, Rosenfeld MG (1996) A CBP integrator complex mediates transcriptional activation and AP-1 inhibition by nuclear receptors. Cell 85: 403-414.

111. Puigserver P, Wu Z, Park CW, Graves R, Wright M, Spiegelman BM (1998) A cold-inducible coactivator of nuclear receptors linked to adaptive thermogenesis. Cell 92: 829-839.

112. Lin J, Wu PH, Tarr PT, Lindenberg KS, St-Pierre J, Zhang CY, Mootha VK, Jager S, Vianna CR, Reznick RM, Cui L, Manieri M, Donovan MX, Wu Z, Cooper MP, Fan MC, Rohas LM, Zavacki AM, Cinti S, Shulman GI, Lowell BB, Krainc D, Spiegelman BM (2004) Defects in adaptive energy metabolism with CNS-linked hyperactivity in PGC-1alpha null mice.
Cell 119: 121-135.

113. Andrulionyte L, Zacharova J, Chiasson JL, Laakso M (2004) Common polymorphisms of the PPAR-gamma2 (Pro12Ala) and PGC-1alpha (Gly482Ser) genes are associated with the conversion from impaired glucose tolerance to type 2 diabetes in the STOP-NIDDM trial. Diabetologia 47: 2176-2184.

114. Caira F, Antonson P, Pelto-Huikko M, Treuter E, Gustafsson JA (2000) Cloning and characterization of RAP250, a novel nuclear receptor coactivator. J Biol Chem 275: 5308-5317.

115. Lee SK, Anzick SL, Choi JE, Bubendorf L, Guan XY, Jung YK, Kallioniemi OP, Kononen J, Trent JM, Azorsa D, Jhun BH, Cheong JH, Lee YC, Meltzer PS, Lee JW (1999) A nuclear factor, ASC-2, as a canceramplified transcriptional coactivator essential for ligand-dependent transactivation by nuclear receptors in vivo. J Biol Chem 274: 34283-34293.

116. Mahajan MA, Samuels HH (2000) A new family of nuclear receptor coregulators that integrate nuclear receptor signaling through CREB-binding protein. $\mathrm{Mol}$ Cell Biol 20: 5048-5063.

117. Zhu Y, Kan L, Qi C, Kanwar YS, Yeldandi AV, Rao MS, Reddy JK (2000) Isolation and characterization of peroxisome proliferator-activated receptor (PPAR) interacting protein (PRIP) as a coactivator for PPAR. $J$ Biol Chem 275: 13510-13516.

118. Ko L, Cardona GR, Henrion-Caude A, Chin WW (2002) Identification and characterization of a tissuespecific coactivator, GT198, that interacts with the DNA-binding domains of nuclear receptors. Mol Cell Biol 22: 357-369.

119. Guerrero-Santoro J, Yang L, Stallcup MR, DeFranco DB (2004) Distinct LIM domains of Hic-5/ARA55 are required for nuclear matrix targeting and glucocorticoid receptor binding and coactivation. $J$ Cell Biochem 92: 810-819.

120. Yang L, Guerrero J, Hong H, DeFranco DB, Stallcup MR (2000) Interaction of the tau 2 transcriptional activation domain of glucocorticoid receptor with a novel steroid receptor coactivator, Hic-5, which localizes to both focal adhesions and the nuclear matrix. Mol Biol Cell 11: 2007-2018.

121. Rachez C, Suldan Z, Ward J, Chang CP, Burakov D, Erdjument-Bromage H, Tempst P, Freedman LP (1998) A novel protein complex that interacts with the vitamin D3 receptor in a ligand-dependent manner and enhances VDR transactivation in a cell-free system. Genes Dev 12: 1787-1800.

122. Fondell JD, Ge H, Roeder RG (1996) Ligand induction of a transcriptionally active thyroid hormone receptor coactivator complex. Proc Natl Acad Sci USA 93: 8329-8333.

123. Ito $\mathrm{M}$, Yuan $\mathrm{CX}$, Malik $\mathrm{S}, \mathrm{Gu} \mathrm{W}$, Fondell JD, Yamamura S, Fu ZY, Zhang X, Qin J, Roeder RG (1999) Identity between TRAP and SMCC complexes indicates novel pathways for the function of nuclear 
receptors and diverse mammalian activators. Mol Cell 3: 361-370.

124. Gu W, Malik S, Ito M, Yuan CX, Fondell JD, Zhang X, Martinez E, Qin J, Roeder RG (1999) A novel human SRB/MED-containing cofactor complex, SMCC, involved in transcription regulation. Mol Cell 3: 97-108.

125. Yuan CX, Ito M, Fondell JD, Fu ZY, Roeder RG (1998) The TRAP220 component of a thyroid hormone receptor-associated protein (TRAP) coactivator complex interacts directly with nuclear receptors in a ligand-dependent fashion. Proc Natl Acad Sci USA 95: 7939-7944.

126. Ito M, Yuan CX, Okano HJ, Darnell RB, Roeder RG (2000) Involvement of the TRAP220 component of the TRAP/SMCC coactivator complex in embryonic development and thyroid hormone action. Mol Cell 5: 683-693.

127. Yanagisawa J, Kitagawa H, Yanagida M, Wada O, Ogawa S, Nakagomi M, Oishi H, Yamamoto Y, Nagasawa H, McMahon SB, Cole MD, Tora L, Takahashi N, Kato S (2002) Nuclear receptor function requires a TFTC-type histone acetyl transferase complex. Mol Cell 9: 553-562.

128. Kato S, Endoh H, Masuhiro Y, Kitamoto T, Uchiyama S, Sasaki H, Masushige S, Gotoh Y, Nishida E, Kawashima H, Metzger D, Chambon P (1995) Activation of the estrogen receptor through phosphorylation by mitogen-activated protein kinase. Science 270 : 1491-1494.

129. Watanabe M, Yanagisawa J, Kitagawa H, Takeyama K, Ogawa S, Arao Y, Suzawa M, Kobayashi Y, Yano T, Yoshikawa H, Masuhiro Y, Kato S (2001) A subfamily of RNA-binding DEAD-box proteins acts as an estrogen receptor alpha coactivator through the $\mathrm{N}$ terminal activation domain (AF-1) with an RNA coactivator, SRA. EMBO J 20: 1341-1352.

130. Endoh H, Maruyama K, Masuhiro Y, Kobayashi Y, Goto M, Tai H, Yanagisawa J, Metzger D, Hashimoto S, Kato S (1999) Purification and identification of p68 RNA helicase acting as a transcriptional coactivator specific for the activation function 1 of human estrogen receptor alpha. Mol Cell Biol 19: 5363-5372.

131. Masuhiro Y, Mezaki Y, Sakari M, Takeyama K, Yoshida $\mathrm{T}$, Inoue $\mathrm{K}$, Yanagisawa J, Hanazawa $\mathrm{S}$, O'Malley BW, Kato S (2005) Splicing potentiation by growth factor signals via estrogen receptor phosphorylation. Proc Natl Acad Sci USA 102: 8126-8131.

132. Ohtake F, Takeyama K, Matsumoto T, Kitagawa H, Yamamoto Y, Nohara K, Tohyama C, Krust A, Mimura J, Chambon P, Yanagisawa J, Fujii-Kuriyama Y, Kato S (2003) Modulation of oestrogen receptor signalling by association with the activated dioxin receptor. Nature 423: 545-550.

133. Adachi M, Takayanagi R, Tomura A, Imasaki K, Kato S, Goto K, Yanase T, Ikuyama S, Nawata H (2000) Androgen-insensitivity syndrome as a possible coactivator disease. $N$ Engl J Med 343: 856-862.
134. Nakamura T, Yao R, Ogawa T, Suzuki T, Ito C, Tsunekawa N, Inoue K, Ajima R, Miyasaka T, Yoshida Y, Ogura A, Toshimori K, Noce T, Yamamoto T, Noda $\mathrm{T}$ (2004) Oligo-astheno-teratozoospermia in mice lacking Cnot7, a regulator of retinoid X receptor beta. Nat Genet 36: 528-533.

135. Chen JD, Evans RM (1995) A transcriptional corepressor that interacts with nuclear hormone receptors. Nature 377: 454-457.

136. Horlein AJ, Naar AM, Heinzel T, Torchia J, Gloss B, Kurokawa R, Ryan A, Kamei Y, Soderstrom M, Glass CK, et al. (1995) Ligand-independent repression by the thyroid hormone receptor mediated by a nuclear receptor co-repressor. Nature 377: 397-404.

137. Kurokawa R, Soderstrom M, Horlein A, Halachmi S, Brown M, Rosenfeld MG, Glass CK (1995) Polarityspecific activities of retinoic acid receptors determined by a co-repressor. Nature 377: 451-454.

138. Alland L, Muhle R, Hou H Jr, Potes J, Chin L, Schreiber-Agus N, DePinho RA (1997) Role for NCoR and histone deacetylase in Sin3-mediated transcriptional repression. Nature 387: 49-55.

139. Heinzel T, Lavinsky RM, Mullen TM, Soderstrom M, Laherty CD, Torchia J, Yang WM, Brard G, Ngo SD, Davie JR, Seto E, Eisenman RN, Rose DW, Glass CK, Rosenfeld MG (1997) A complex containing N-CoR, $\mathrm{mSin} 3$ and histone deacetylase mediates transcriptional repression. Nature 387: 43-48.

140. Nagy L, Kao HY, Chakravarti D, Lin RJ, Hassig CA, Ayer DE, Schreiber SL, Evans RM (1997) Nuclear receptor repression mediated by a complex containing SMRT, mSin3A, and histone deacetylase. Cell 89: 373-380.

141. Guenther MG, Lane WS, Fischle W, Verdin E, Lazar MA, Shiekhattar R (2000) A core SMRT corepressor complex containing HDAC3 and TBL1, a WD40repeat protein linked to deafness. Genes Dev 14: 10481057.

142. Li J, Wang J, Nawaz Z, Liu JM, Qin J, Wong J (2000) Both corepressor proteins SMRT and N-CoR exist in large protein complexes containing HDAC3. EMBO J 19: 4342-4350.

143. Ciechanover A, Orian A, Schwartz AL (2000) Ubiquitin-mediated proteolysis: biological regulation via destruction. Bioessays 22: 442-451.

144. Perissi V, Aggarwal A, Glass CK, Rose DW, Rosenfeld MG (2004) A corepressor/coactivator exchange complex required for transcriptional activation by nuclear receptors and other regulated transcription factors. Cell 116: 511-526.

145. Shibata H, Nawaz Z, Tsai SY, O’Malley BW, Tsai MJ (1997) Gene silencing by chicken ovalbumin upstream promoter-transcription factor I (COUP-TFI) is mediated by transcriptional corepressors, nuclear receptorcorepressor $(\mathrm{N}-\mathrm{CoR})$ and silencing mediator for retinoic acid receptor and thyroid hormone receptor (SMRT). Mol Endocrinol 11: 714-724. 